\title{
Competing frames and tone in corporate communication versus media coverage during a crisis
}

\author{
Jos Nijkrake ${ }^{\mathrm{a}}$, Jordy F. Gosselt ${ }^{\mathrm{a}, *}$, Jan M. Gutteling ${ }^{\mathrm{b}}$ \\ a University of Twente, Department of Communication Studies, The Netherlands \\ b University of Twente, Department of Conflict, Risk and Safety, The Netherlands
}

\section{A R T I C L E I N F O}

\section{Article history:}

Received 29 April 2014

Received in revised form 13 October 2014

Accepted 30 October 2014

\section{Keywords:}

Competing frames

Crisis communication

Crisis response strategy

Framing

Tone

Media coverage

\begin{abstract}
A B S T R A C T
Managing corporate communication through a crisis response strategy may limit negative media coverage, thereby affecting public perceptions during crisis situations. However, because different stakeholders are being informed via multiple channels, different messages may reach the public, creating competing frames. This study examines how an organization's crisis response affects media coverage. Using content analysis, media coverage messages $(N=128)$ and corporate communication messages $(N=24)$ were compared regarding an organization in crisis. All messages were analyzed considering five news frames and tone (ranging from very negative to very positive) toward internal and external stakeholders. Findings indicate that the media reframed corporate communication messages, using more and different news frames than the organization in crisis. Furthermore, media coverage messages and corporate communication messages differed in the mentioned aspects within various news frames. All stakeholders are covered significantly more negatively in media coverage.
\end{abstract}

(c) 2014 Elsevier Inc. All rights reserved.

In April 2011, a midsized hospital in a major city in the Netherlands was confronted with a bacteria outbreak. The outbreak was leading to hundreds of patients being infected by the Klebsiella pneumoniae bacteria and for at least three people the bacteria was the direct cause of death. Consequently, the hospital was put under stricter surveillance by the Dutch Health Care Inspectorate, the hospital manager resigned, and the bacteria outbreak was being investigated by several independent commissions. Further, for the hospital - that was involved in a large-scale relocation to a new building this was not the first bacteria outbreak. As a result of a large bacteria outbreak in 2002 and a temporary closing due to a bacteria outbreak in 2010, the hospital already had a crisis history. From late May 2011, the hospital's stakeholders were proactively informed about the crisis situation by means of press releases. However, especially in times of crisis, stakeholders tend to rely on media coverage because information through the media is being perceived as more credible than direct communication (Bond \& Kirshenbaum, 1998). Although existing literature underlines the importance of a(ny) crisis response (e.g., reputational damage control), the relation between an organization's crisis response and the contents of media coverage is still understudied. Thus, in this study, corporate communication about a crisis - in the form of press releases - is compared to media coverage regarding the same crisis.

\footnotetext{
* Corresponding author at: University of Twente, Faculty of Behavioral Sciences, Department of Communication Studies, P.O. Box 217, 7500 AE Enschede, The Netherlands. Tel.: +31 053489 6130; fax: +31053 4894259 .

E-mail address: j.f.gosselt@utwente.nl (J.F. Gosselt).
} 


\section{Theoretical framework}

\subsection{Crisis communication from an organizational perspective}

Coombs (2007) defines a crisis as “a sudden and unexpected event that threatens to disrupt an organization's operations and poses both a financial and a reputational threat." Because crises are characterized by high levels of uncertainty, without timely information dissemination, chances are that rumors will dominate the crisis discourse, increasing uncertainty and exacerbating the situation (Veil \& Ojeda, 2010). Therefore, organizations need to determine how to communicate with their various stakeholders to preserve the relationship (Stephens \& Malone, 2009), especially because it is assumed corporate communication during and after a crisis is one of the most important factors in determining the long-term effects of a crisis (Coombs, 1999). Corporate communication can limit negative media coverage and manage perceptions both during a crisis and at the recovery/resolution stage (Ritchie, Dorell, Miller, \& Miller, 2004).

Crisis communication managers may try to frame the crisis is such a way that reputational damage to the organization should be minimized. Framing refers to highlighting bits of information about an item that is the subject of a communication, thereby elevating them in salience (Entman, 1993). The way a message is framed shapes how people define problems, causes of problems, attributions of responsibility, and solutions to problems (Cooper, 2002), ultimately influencing public perception (Bullock, Wyche, \& Williams, 2001). Therefore, creating frames for understanding and offering explanatory definitions are both crucial for effective communication during a crisis (Coombs, 1999), as they indicate how stakeholders should interpret a crisis (Coombs \& Holladay, 2002). By means of press releases or news releases, produced by organizations wishing to highlight certain circumstances or to provide a given interpretation of events, these frames are then distributed to various media channels in the hope that the latter will republish the information to reach a wide audience (Gilpin, 2008). However, the question is whether these frames will be supported or not by other stakeholders with a wide access to the public, namely the news media.

\subsection{Crisis communication from a media coverage perspective}

Most of the information to stakeholders is provided by the news media, not by corporate communication (Coombs, 2007), making the media the final arbiter of crisis frames in most cases. Where organizations want to reduce uncertainty and repair their reputation in times of crisis (e.g., Coombs, 2007), overt goals of mass media are primarily to inform and entertain (McCombs, 1977). Although the media do not create a crisis, they can move them to center stage or keep them out of public view (Nelkin, 1988), and through deliberate coverage of events and issues, the media have the ability to set the agenda for public discussion (Barnes, Hanson, Novilla, Meacham, \& McIntyre, 2008). Thus, journalists' daily decisions do significantly influence their audience's pictures of the world (Carroll \& McCombs, 2003). Given the different goals and stakes for an organization in crisis and journalists, it is likely to assume that media coverage and corporate communication differ in the way they communicate about a crisis (i.e., in terms of the tone toward stakeholders, and facts included or emphasized; McCombs \& Ghanem, 2001).

In general, tone can be positive, neutral or negative and influences audience members to think in a certain way about a particular issue (Brunken, 2006). Similarly, Deephouse (2000) states that an organization can be subject to media coverage that is favorable (i.e., an organization is praised for its actions), unfavorable (i.e., an organization is criticized for its actions), or neutral (i.e., no evaluative modifier is included in the media coverage). Several studies have found that the tone in media coverage has a significant effect on public opinion (see for example: Gunther, 1998; Kim, Carvalho, \& Cooksey, 2007). Furthermore, and not surprisingly, tone in media coverage concerning parties involved in a crisis (e.g., employees, investors, management, governments) tends to be mainly negative or neutral. However, because these parties may differ in their levels of responsibility, blame, and/or involvement, tone toward these parties may vary (Valentini \& Romenti, 2011). For example, although tone in media coverage of Hurricane Katrina varied depending on the different levels of government in the coverage, the general tone was relatively neutral (Brunken, 2006). Regarding the explosions at a fireworks facility in the Netherlands in 2000, the tone was mildly negative toward local and national governments (Kuttschreuter, Gutteling, \& de Hond, 2011). In sum: very few news stories involving a crisis are positively covered. However, in terms of tone, differences do exist concerning the various parties involved in a crisis.

In addition to tone, the content of media coverage is also characterized by the presence of certain news frames. News frames can affect perceptions of issues and of people in the news (Price, Tewksbury, \& Powers, 1997). By prompting the activation of certain constructs at the expense of others, news frames can directly influence what enters the minds of audience members. Concerning Neuman, Just, and Crigler's (1992) four dominant news frames (i.e., conflict, economic consequences, morality, and human impact), Semetko and Valkenburg (2000) added the responsibility frame and renamed the human-impact frame into human-interest frame. The human-interest frame brings an emotional, personal angle to the presentation of an event, and the responsibility frame is present when some actor (e.g., an individual or organization) is held responsible for the causes of an event. Both these news frames might stimulate the formation of more negative attitudes toward the crisis and perhaps also the organization that is blamed for the crisis (An \& Gower, 2009). News stories with a conflict frame emphasize conflicts between individuals, groups or organizations. The conflict frame is very common in newspapers and other news media (Semetko \& Valkenburg, 2000; Neuman et al., 1992) and it is to be expected that it might contribute to the attribution of blame to the organization in crisis. The economic-consequences frame reports an issue in 
terms of consequences it will financially have on an individual, group, organization, or region. When crises involve larger economic consequences, this frame will be more present in the news. News stories put in the context of moral prescriptions are framed in terms of morality. Rather than because of the journalistic norm of objectivity, the morality frame is commonly used by journalist indirectly through quotations or inference (Neuman et al., 1992).

The presence of these five dominant news frames activates explicit thoughts and responses among the public (Cappella \& Jamieson, 1997; Cho \& Gower, 2006; de Vreese, 2004; Iyengar, 1987; Valkenburg, Semetko, \& de Vreese, 1999). Cho and Gower (2006) suggest that a human-interest frame can stimulate the emotional responses by exaggerating the evaluation or perception of crises. By presenting winners and losers, a story framed in terms of conflict can activate the cynical reactions among members of the public (Cappella \& Jamieson, 1997), often including more and opposing points of view in their thoughts (de Vreese, 2004). A news story framed in terms of economic consequences will activate thoughts and responses concerning the costs, benefits and financial implications of involved parties (Valkenburg et al., 1999; de Vreese, 2004). Finally, Iyengar (1987) suggests that a news story framed in terms of attribution of responsibility provides the public with more understanding regarding which party is responsible for causing problems.

Given the reliance on media during a crisis (Brunken, 2006), a frame analysis concerning media coverage in times of crisis is deemed important. Consequently, more recent framing research focused on news frames during crisis situations (e.g., An \& Gower, 2009; Brunken, 2006; Kuttschreuter et al., 2011; Valentini \& Romenti, 2011). Brunken (2006) found that the human-interest frame was the one most used in media coverage about Hurricane Katrina, followed by the conflict frame, the responsibility frame, the economic-consequences frame, and the morality frame. Furthermore, the presence of the human-interest frame dropped considerably after the first three weeks of coverage. Valentini and Romenti (2011) found that the economic-consequences frame was the one most used in media coverage about Alitalia's crisis before its privatization, followed by the conflict frame, the responsibility frame, the human-interest frame, and the morality frame. In media coverage concerning explosions at a fireworks facility in the Netherlands killing 23 people, Kuttschreuter et al. (2011) found that the responsibility frame was the one most used, followed by the conflict frame, the human-interest frame, and the economic-consequences frame. The morality frame was not present in the media coverage of the explosions. An and Gower (2009) found that the responsibility frame was the one most used in media coverage concerning 25 organizations that faced crises in 2006, followed by the economic-consequences frame, the human-interest frame, the conflict frame, and the morality frame. In the An and Gower's study, however, the level of responsibility was also taken into account, showing that if a crisis was seen as preventable, news stories were more likely to use the responsibility frame, conflict frame and morality frame. Further, accidental crises were predominantly framed in terms of economic-consequences and the human-interest frame was used more often when the crisis type was in the victim cluster.

To conclude, these studies on media coverage of crises situations reveal that the morality frame is less likely to be used as a news frame, whereas the conflict frame and the responsibility frame appear to be used more often, followed by the human-interest frame and the economic-consequences frame. Another conclusion that can be drawn is that frame use is dependent on the level of responsibility attributed to the organization.

\subsection{Competing frames}

By presenting their own interpretation of an issue, organizations frame their communications while news media participate in the process by accepting and modifying the frames presented to them (Miller \& Riechert, 2000).

In order to keep a story alive and fresh, media often reframe an event by emphasizing different attributes (McCombs, 2004). For example, because of insufficient knowledge about the matter, in their initial coverage, a journalist may heavily rely on the sources that provide information, including the organization at hand. However, in their subsequent search for facts, journalists may prefer speaking to eyewitnesses, or experts, while statements from spokespersons may be treated with skepticism (Miller \& Riechert, 2000). Consequently, as noted above, the audience can be exposed to multiple news frames for one particular issue (Edy \& Meirick, 2007), leading to a situation in which people are continuously exposed to various competing arguments (Hansen, 2007). Coombs (2007) defines this process as competing frames. Confronted with competing frames, the audience will combine these to build stories of their own (Edy \& Meirick, 2007). In presenting their side of the story, crisis managers may take advantage from this by establishing a frame or reinforcing an existing one. On the other hand, news media may reject the crisis manager's frame and continue with a different frame (Coombs, 2007). Where early studies (e.g., Iyengar, 1987) have explored the impact of one single frame on audience opinion, counter-framing (i.e., where an alternative frame is offered) and heterogeneous discussions limit framing effects by prompting deliberate processing and offering reformulations of the problems (Druckman, 2004). In an experimental study, Druckman (2004) found that when presenting different frames to audiences (i.e., a frame with the original problem, but also a reframing of the problem that uses the opposite frame), framing effects appear to be neither robust not particularly pervasive.

In this study, based on the theoretical concept of competing frames, we will examine the presence of competing frames in corporate communication (i.e., press releases) versus media coverage regarding one specific crisis situation. Furthermore, we will explore whether differences exist concerning relevant stakeholders with regard to frame use and tone. We expect that the hospital in crisis will focus on a rebuild strategy in order to generate new reputational assets. Adopting this strategy may be an attempt to change perceptions of the organization in crisis by presenting new, positive information about the organization and to offset the negatives from the crisis with current good works. Therefore, we expect that the hospital will 
adjust information by expressing concern for the victims and that solutions to the crisis will be offered. Regarding frame use, we expect that the hospital frames its corporate communication mainly in terms of human-interest and responsibility. Taking the media coverage perspective, in case of a preventable crisis, we expect that news stories are likely to be framed in terms of responsibility, conflict and morality. To summarize the previous discussions, these are the research questions that will be analyzed: RQ1: To what extend does an organization's crisis response affect media coverage in terms of news frames? RQ2: To what extent does an organization's crisis response affect media coverage in terms of tone toward concerned parties?

\section{Method}

By means of a content analysis, the corporate communication of an organization in crisis (i.e., the hospital where the bacteria outbreak took place) is compared with media coverage on this subject, focusing on tone as well as the news frames that were used.

\subsection{Corpus of press releases and news articles}

From the hospital's website, all press releases related to the bacteria outbreak $(N=24)$ were retrieved and analyzed. Regarding the corporate communication coverage, the unit of analysis was one press release. For the media coverage, the unit of analysis was one newspaper article. Prior to determining a final sample, national and regional newspapers with the largest circulation in the Netherlands were selected (De Persgroep Advertising, 2013; HOI, Instituut voor Media Auditing, 2011). National newspapers were selected based solely on the focus and on the circulation in the crisis area. Regarding the regional newspapers, the most important inclusion criterion was the geographical circulation in the crisis area. We selected two regional newspapers: the newspaper with the largest circulation in the crisis region and a newspaper without circulation in the crisis area to portray media coverage in Dutch newspapers as completely as possible (Cebuco, 2012; De Persgroep Advertising, 2013). Regarding both national and regional papers, in order to reveal the presence of frames, newspapers covering background news were selected over newspapers covering shallow news. As expected, these quality newspapers cover news stories more extensively and as such, returned the largest numbers of hits in the electronic databases. All news articles were retrieved from the Lexis-Nexis database and of all relevant articles, duplicates were excluded. The final sample $(N=128)$ consisted of two national newspapers (NRC Handelsblad, $N=27$; Trouw, $N=25)$ and two regional newspapers (Rotterdams Dagblad, $N=57$; Brabants Dagblad, $N=19$ ) with circulation in the crisis area and outside the crisis area, respectively.

\subsection{Coding procedure and reliability}

The coding procedure consisted of two parts. The first part concerned tone toward internal stakeholders (i.e., the organization in general, employees [e.g., microbiologists, hygienists, nurses], and management [e.g., the board, the management, the (interim) director]), and external stakeholders (including local government [e.g., the mayor, the city councillor, the municipality] and national government). A third stakeholder group that was incorporated concerned - independent research councils (including organizations such as The National Institute for Public Health, Community Health Services, The Health Care Inspectorate and other specially equipped commissions of inquiry). Tone was coded separately for these subgroups, on five-point scales (ranging from very negative to very positive). Based on Meijer and Kleinnijenhuis (2006), tone could take one of the following values: $-2,-1,0,+1$ and +2 . The values " -1 " and " +1 " were used when a refinement was made to the text (such as "maybe," "slightly," and "perhaps"). The context unit consisted of the article as a whole.

The second part of the coding procedure assessed the presence of frames in both the corporate communication and the news coverage. This was coded according to Semetko and Valkenburg's (2000) framework. This framework involves the following frames: the human-interest frame (i.e., this frame brings an emotional, personal angle to the presentation of an event), the responsibility frame (i.e., this frame holds some actor responsible for the causes of an event), the conflict frame (i.e., this frame emphasizes conflicts between individuals, groups, or organizations), the economic-consequences frame (i.e., this frame reports an issue in terms of economic consequences on an individual, group, organization, or region), and the morality frame (i.e., this frame puts stories in the context of moral prescriptions). For each article, the presence and contents of the preceding frames were analyzed by answering three or more statements, which characterize a particular news frame (yes, no), so multiple frames could be present within one article.

Prior to coding the final corpus, several samples were drawn to achieve a minimum Cohen's kappa score of approximately .7. To prevent eventual biases, the samples varied. For the intercoder reliability test, two coders were subjected to a coding instruction and coded 48 randomly selected newspaper articles. These represented approximately $10 \%$ of the total publications per newspaper. After three completed samples, all variables showed a sufficient Cohen's kappa (see Table 1). 
Table 1

Cohen's kappa and interrater agreement scores.

\begin{tabular}{|c|c|c|c|}
\hline & Variable & Cohen's kappa & Interrater agreement \\
\hline \multirow{6}{*}{ Tone } & Organization in general & .865 & $93 \%$ \\
\hline & Employees & .871 & $92 \%$ \\
\hline & Management & .682 & $79 \%$ \\
\hline & Local government & .707 & $83 \%$ \\
\hline & National government & .716 & $90 \%$ \\
\hline & Research council & .755 & $85 \%$ \\
\hline \multirow{5}{*}{ News frames } & Human interest & 1.00 & $100 \%$ \\
\hline & Conflict & .837 & $100 \%$ \\
\hline & Responsibility & 1.00 & $100 \%$ \\
\hline & Economic consequences & .705 & $85 \%$ \\
\hline & Morality & 1.00 & $79 \%$ \\
\hline
\end{tabular}

\section{Results}

\subsection{News frames}

The news frames used within the corpus are shown in Table 2. In media coverage, the total number of distinctive news frames per article $(M=2.02, S D=.887)$ is higher than in corporate communication coverage $(M=1.13, S D=.448) ; t$ $(63.01)=7.39, p<01$. Corporate communication was framed most frequently in terms of human interest (96\%; of which 65\% provided a human example on the issue and $61 \%$ told how individuals and groups are affected), followed by the conflict frame (13\%; of which $67 \%$ reflected on disagreements between parties and $33 \%$ emphasized one party that reproaches another), and the economic consequences frame (4\%; in all these cases the costs were mentioned). None of the press releases were framed in terms of responsibility or morality. Also media coverage was framed most frequently in terms of human interest

Table 2

Use of news frames in media coverage and corporate communication.

\begin{tabular}{|c|c|c|c|}
\hline & $\begin{array}{l}\text { I. Media } \\
\text { coverage }\end{array}$ & $\begin{array}{l}\text { II. Corporate } \\
\text { communication }\end{array}$ & I vs. II \\
\hline Human-interest frame & $96 \%$ & $96 \%$ & n.s. \\
\hline The story provides a human example or 'human face' on the issue & $75 \%$ & $65 \%$ & n.s. \\
\hline The story employs adjectives or personal vignettes that generate feelings of outrage & $2 \%$ & $0 \%$ & n.s. \\
\hline The story emphasizes how individuals and groups are affected by the issue/problem & $84 \%$ & $61 \%$ & $5.10^{*}$ \\
\hline The story goes into the private or personal lives of the actors & $11 \%$ & $0 \%$ & n.s. \\
\hline The story refers to non-direct victims of the issue & $3 \%$ & $0 \%$ & n.s. \\
\hline Conflict frame & $67 \%$ & $13 \%$ & $24.91^{* *}$ \\
\hline The story reflects disagreements between parties-individuals-groups-countries & $16 \%$ & $67 \%$ & n.s. \\
\hline One party-individual-group-country does reproach another & $95 \%$ & $33 \%$ & $26.10^{* *}$ \\
\hline The story refers to two or more sides of the problem or issue & $0 \%$ & $0 \%$ & \\
\hline The story refers to winners and losers & $0 \%$ & $0 \%$ & \\
\hline The story refers to parties which defend themselves against criticism & $7 \%$ & $0 \%$ & n.s. \\
\hline Responsibility frame & $16 \%$ & $0 \%$ & $4.32^{*}$ \\
\hline The story suggests that some level of government has the ability to alleviate the problem & $0 \%$ & $0 \%$ & \\
\hline The story suggests that some level of the government is responsible for the issue/problem & $5 \%$ & $0 \%$ & n.s. \\
\hline The story suggests solution(s) to the problem/issue & $10 \%$ & $0 \%$ & n.s. \\
\hline The story suggests that an individual (or group of people in society) is responsible for the issue/problem & $95 \%$ & $0 \%$ & $4.07^{*}$ \\
\hline The story suggests the problem requires urgent action & $0 \%$ & $0 \%$ & \\
\hline The story refers to potential problems & $0 \%$ & $0 \%$ & \\
\hline Economic-consequences frame & $22 \%$ & $4 \%$ & $4.12^{*}$ \\
\hline There is a mention of financial losses or gains now or in the future & $36 \%$ & $0 \%$ & n.s. \\
\hline There is a mention of costs/degree of expenses involved & $96 \%$ & $100 \%$ & $3.85^{*}$ \\
\hline There is a reference to economic consequences of pursuing or not pursuing a course of action & $7 \%$ & $0 \%$ & n.s. \\
\hline Morality frame & $1 \%$ & $0 \%$ & n.s. \\
\hline The story does contain a moral message & $0 \%$ & $0 \%$ & \\
\hline The story does make a reference to morality, God and other religious tenets & $0 \%$ & $0 \%$ & \\
\hline The story offers specific social prescriptions about how to behave & $100 \%$ & $0 \%$ & n.s. \\
\hline The story refers to intentional bad behavior & $0 \%$ & $0 \%$ & \\
\hline Total number of news frames & 258 & 27 & $7.39^{* *}$ \\
\hline Number of news frames per article & 2.0 & 1.1 & \\
\hline
\end{tabular}

${ }^{*} p<.05$.

** $p<01$. 
Table 3

Average tone toward relevant stakeholders in media coverage and corporate communication.

\begin{tabular}{|c|c|c|c|c|c|}
\hline & \multicolumn{2}{|c|}{ I. Media coverage } & \multicolumn{2}{|c|}{ II. Corporate communication } & \multirow[t]{2}{*}{ I vs. II ( $t$-tests) } \\
\hline & $M$ & $S D$ & $M$ & $S D$ & \\
\hline Internal stakeholders & -.43 & .476 & .04 & .204 & $-7.94^{* *}$ \\
\hline External stakeholders & .00 & .000 & & & \\
\hline Organization in general & -.44 & .637 & .00 & .000 & $-7.77^{* *}$ \\
\hline Employees & -.56 & .585 & .00 & .000 & $-7.78^{* *}$ \\
\hline Management & -.48 & .623 & .25 & .707 & $-3.11^{* *}$ \\
\hline Local government & .00 & .000 & & & \\
\hline National government & .00 & .000 & & & \\
\hline Research council & -.06 & .241 & .00 & .000 & $-2.29^{*}$ \\
\hline Overall tone & -.32 & .372 & .03 & .136 & $-8.16^{* *}$ \\
\hline
\end{tabular}

${ }^{*} p<.05$

** $p<01$.

(96\%; $84 \%$ of which focused on how individuals and groups are affected by the issue and $75 \%$ provided a human example on the issue), conflict (67\%; of which 95\% emphasized one party that reproaches another), and economic consequences (22\%; of which $96 \%$ involved mentioning costs/degree of expenses). Furthermore, different from corporate communication, in media coverage also the responsibility frame (16\%; of which $95 \%$ because an individual or group is suggested to be responsible for the issue), and the morality frame (1\%; all because of specific social prescriptions about how to behave) were present.

Frame use appeared to differ by communication type. For example, the use of the conflict frame differed significantly by communication type $\left(\chi^{2}(1, N=152)=24.91, p<.001\right)$, indicating that media coverage was framed significantly more often in terms of conflict (67\%) than was corporate communication (13\%). Furthermore, Fisher's exact tests revealed that the use of the responsibility frame $(p=.044)$ and the economic-consequences frame $(p=.048)$ significantly differed per communication type, showing that media coverage compared to corporate communication was framed significantly more often in terms of responsibility ( $16 \%$ vs. $0 \%$ ) and economic consequences ( $22 \%$ vs. $4 \%$ ). No differences were found in the use of the human-interest frame and the morality frame.

Additionally, Chi-squared tests and Fisher's exact tests were performed to give insight into the differences between the contents of the frames per communication type. First, although we found no differences in the frequency of use of the human-interest frame in general when comparing corporate communication with media coverage, the contents of the human interest frame did differ by communication type $\left(\chi^{2}(1, N=152)=5.10, p<.05\right)$, indicating that media coverage was framed significantly more often in terms of how individuals and groups are affected by the issue (84\%) than was corporate communication (61\%). Second, regarding the conflict frame, media coverage was framed significantly more often in terms of one party or group reproaching another $(95 \%)$ as compared to corporate communication $\left(33 \% ; \chi^{2}(1, N=152)=26.10\right.$, $p<.001)$. Third, Fisher's exact test revealed that the responsibility frame $(p=.04)$ significantly differed per communication type, showing that media coverage compared to corporate communication was framed significantly more often in terms of suggesting that an individual (or group of people in society) is responsible for the issue compared corporate communication (95\% vs. 0\%). Fourth, Fisher's exact test revealed that the economic-consequences frame $(p=.08)$ significantly differed per communication type, showing that corporate communication compared to media coverage was framed significantly more often in terms of mentioning costs/degrees of expenses (100\% vs. $96 \%$ ). No differences were found regarding the contents of the morality frame.

\subsection{Tone}

Independent-samples $t$-tests were conducted to compare tone toward relevant stakeholders for each crisis response type (see Table 3$)$. Overall, tone was significantly more negative in media coverage $(M=-.32, S D=.372)$ when compared to corporate communication $(M=.03, S D=.136) ; t(97.84)=-8.16, p<.01$. The external stakeholders local government and national government were not covered in corporate communication. In media coverage, local government $(M=.00, S D=.000)$, and national government $(M=.00, S D=.000)$ were on average covered in a neutral tone. The internal stakeholders were covered significantly more negatively in media coverage $(M=-.43, S D=.476)$ than in corporate communication coverage $(M=.04, S D=.204) ; t(79.03)=-7.94, p<.01$. When considering the internal stakeholders separately, all internal stakeholders were covered significantly more negatively in media coverage, as compared to corporate communication (organization in general: $M=-.44, S D=.637$ versus $M=.00, S D=000 ; t(127)=-7.77, p<.01)$; employees: $M=-.56, S D=.585$ versus $M=.00$, $S D=.000 ; t(65)=-7.78, p<.01$; management: $M=-.48, S D=.623$ versus $M=25, S D=.707 ; t(81)=-3.11, p<.01)$. Further, the research council was covered significantly more negatively in media coverage $(M=-.06, S D=.241)$ than in corporate communication coverage $(M=.00, S D=.000), t(81)=-2.29, p<.05$. 
Table 4

Average tone per news frame and correlations between tone and news frames in media coverage and corporate communication.

\begin{tabular}{|c|c|c|c|c|c|c|}
\hline & $\begin{array}{l}\text { Organization in } \\
\text { general }\end{array}$ & Employees & Management & Local government & $\begin{array}{l}\text { National } \\
\text { government }\end{array}$ & Research council \\
\hline \multicolumn{7}{|l|}{ Media coverage } \\
\hline Human interest & -.44 & -.57 & -.48 & .00 & .00 & -.06 \\
\hline Conflict & $-.65^{* *}$ & $-.69^{* *}$ & $-.56^{* *}$ & .00 & .00 & -.07 \\
\hline Responsibility & $-.75^{*}$ & $-.89^{* *}$ & -.68 & .00 & .00 & -.11 \\
\hline Economic consequences & -.25 & -.50 & -.60 & .00 & .00 & -.07 \\
\hline Morality & .00 & & -1.00 & & .00 & .00 \\
\hline Total number of articles & 128 & 66 & 75 & 2 & 12 & 82 \\
\hline \multicolumn{7}{|l|}{ Corporate communication } \\
\hline Human interest & .00 & .00 & .29 & .00 & & \\
\hline Conflict & .00 & .00 & .00 & .00 & & \\
\hline Responsibility & & & & & & \\
\hline $\begin{array}{l}\text { Economic consequences } \\
\text { Morality }\end{array}$ & .00 & & $2.00^{* *}$ & .00 & & \\
\hline Total number of articles & 24 & 6 & 8 & 22 & & \\
\hline
\end{tabular}

Note: Tone ranges from -2 (very negative) to +2 (very positive).

${ }^{*} p<05$.

** $p<01$.

\subsection{Correlation news frames and tone}

In corporate communication, the economic consequences frame is significantly correlated with tone toward management $(r(6)=1.00)$ : tone toward management is more positive when the press releases are framed in terms of economic consequences, see Table 4.

In media coverage, tone is significantly correlated with the conflict frame toward internal stakeholders: when media coverage is framed in terms of conflict, tone toward internal stakeholders becomes more negative. The responsibility frame is significantly correlated with the organization in general and with employees: when media coverage is framed in terms of responsibility, tone toward these stakeholders becomes more negative. The economic-consequences frame was significantly correlated with tone toward management: When corporate communication is framed in terms of economic consequences, tone toward management becomes more positive.

\subsection{Timelines, news frames and tone}

To gather insight in the development of news frames and average tone toward relevant stakeholders, chronological timelines were created. On these timelines, key events during the crisis were marked. In both media coverage and corporate communication, messages in the first month were predominantly framed in terms of human interest. Further, both communication types are characterized by several peaks over time. These peaks occur approximately at the same time. The used news frames in these fluctuations, however, differ. Corporate communication coverage is only framed in terms of human interest, conflict and economic consequences, and after three months, the only frame that persists is the humaninterest frame. Furthermore, the economic-consequences frame is used in media coverage before it is used in corporate communication.

Regarding tone in media coverage, despite a slight peak in August 2011, which is characterized by a positive tone, internal stakeholders were only covered neutrally in corporate communication coverage and external stakeholders were not mentioned at all. In media coverage, external stakeholders were only covered neutrally. Except for the months June 2012 and August 2012, internal stakeholders were covered negatively. When comparing the average tone toward relevant stakeholders in corporate communication coverage and in media coverage, several statements can be made. The first six months of the crisis (i.e., June 2011-November 2011), were characterized by corporate communication, which was mainly neutral toward internal stakeholders. After this period, press releases were purely neutral and published in January 2012 , March 2012 and August 2012. However, the media did focus on the crisis for five months in a row. Furthermore, the media published news stories in more months (i.e., 12) than the organization in crisis (i.e., 9) during the entire crisis.

\section{Discussion}

The primary goal of this research was to examine in what way a corporate crisis response strategy affects media coverage. Using content analysis, media coverage messages and corporate communication messages were compared. The organization in crisis was a midsized hospital in a major city in the Netherlands that was confronted with a bacteria outbreak leading to hundreds of patients being infected by the K. pneumoniae bacteria, resulting in three fatalities. Although previous studies (Ulmer, Sellnow, \& Seeger, 2007; Veil \& Ojeda, 2010) indicate that organizations in crisis interacting with the media may 
have influence on those media, resulting in pro-organization media coverage, we did not find evidence supporting this claim. Instead, it appeared that an organization's crisis response is constantly being reframed by the news media.

To illustrate, our results show that the media frame a crisis significantly more often in terms of conflict, responsibility and economic consequences compared to communications issued by the organization. Furthermore, significant differences were found within the news frames used. In order to generate new reputational assets, the organization in crisis was expected to offer solutions (i.e., which is an aspect of the responsibility frame). As this news frame got no attention in the press releases, the media introduced their own stories about which party can be held responsible. Furthermore, in absence of provided solutions and/or new, positive news by the organization in crisis, the news media also focused on the parties that reproached another and reflected disagreements (i.e., conflict frame) significantly more than the organization in crisis did. Also, concerning the human-interest frame, the media emphasized how individuals and groups are affected by the crisis significantly more than corporate communications. The average number of news frames per article is higher in media coverage (i.e., 2) than in corporate communication coverage (i.e., 1.1). Further, a chronological timeline analysis showed that corporate communication in approximately the first three months is framed most frequently in terms of human interest, conflict, and economic consequences. After this period, corporate communication is only covered in terms of human interest. However, in media coverage, a variety of news frames is used during the entire period of crisis. Also, the economic-consequences frame is used in media coverage before it is used in corporate communication.

The reframing character of news media is also illustrated by significant differences in terms of tone, compared to corporate communication. Ritchie et al. (2004) suggest managing corporate communication through a crisis response strategy to limit negative media coverage. However, the present results show that all stakeholders (that appear in corporate communication) are covered significantly more negatively in media coverage compared to corporate communication. Furthermore, in the media, more stakeholders are covered than in corporate communication (e.g., the local government and national government were addressed in media coverage and not in corporate communication). Therefore, it can be stated that not covering certain stakeholders in corporate communication is no guarantee that the media will not do so either. In sum, despite proactively framing a crisis through corporate communication coverage, the organization in crisis has not been able to prevent negative media coverage of internal stakeholders.

One might wonder how crisis managers should deal with the reframing nature of news media? Proactively responding to a crisis is by no means a guarantee that the media will adopt your frame. The most important practical implication for crisis managers is that mainly framing the crisis in terms of human interest is not enough to positively affect media coverage, as results from this study suggest that the media will reframe the organization's crisis response predominantly in terms of conflict, responsibility and economic consequences. Does this imply that corporate crisis communication is being ignored by the media (and the rest of the world) because it apparently is ignoring reality? When this is a valid argument, what would the utility of corporate crisis communication be?

Some limitations of this study must be noted. The first is that this study's organization in crisis used only one news frame to address a limited set of stakeholders neutrally. So, it remains unclear what happens to media reframing when the organization in crisis frames the crisis in more than one news frame and when it will address relevant stakeholders more negatively. Additional research is needed to test this. A second limitation concerns the type of media coverage, which is used for this study. This research only included media coverage from newspapers. Given the rising popularity of digital media and social media, it is recommended to include news websites, or weblogs, or social media channels in future research.

\section{References}

An, S.-K., \& Gower, K. K. (2009). How do the news media frame crises? A content analysis of crisis news coverage. Public Relations Review, 35, 107-112. http://dx.doi.org/10.1016/j.pubrev.2009.01.010

Barnes, M. D., Hanson, L., Novilla, L. M., Meacham, A. T., \& McIntyre, E. (2008). Analysis of media agenda setting during and after Hurricane Katrina: Implications for emergency preparedness, disaster response, and disaster policy. American Journal of Public Health, 98(4), 604-610. http://dx.doi.org/10.2105/AJPH.2007.112235

Bond, J., \& Kirshenbaum, R. (1998). Under the radar: Talking to today's cynical consumer. New York: John Wiley \& Sons Inc

Brunken, B. L. (2006). Hurricane Katrina: A content analysis of media framing, attribute agenda setting, and tone of government response. Louisiana State University. Retrieved from http://etd.lsu.edu/docs/available/etd-07102006-130303/

Bullock, H. E., Wyche, K. F., \& Williams, W. R. (2001). Media images of the poor. Journal of Social Issues, 57(2), 229-246. http://dx.doi.org/10.1111/0022-4537.00210

Cappella, J. N., \& Jamieson, K. H. (1997). Spiral of cynicism: The press and the public good. New York: Oxford University Press.

Carroll, C. E., \& McCombs, M. (2003). Agenda-setting effects of business news on the public's images and opinions about major corporations. Corporate Reputation Review, 6(1), 36-46. http://dx.doi.org/10.1057/palgrave.crr.1540188

Cebuco. (2012). Verspreide oplage per titel per provincie 2012. Amsterdam: NDP Nieuwsmedia. Retrieved from http://www.oplagen-dagbladen.nl/

Cho, H. S., \& Gower, K. K. (2006). Framing effect on the public's response to crisis: Human interest frame and crisis type influencing responsibility and blame. Public Relations Review, 32, 420-422. http://dx.doi.org/10.1016/j.pubrev.2006.09.011

Coombs, W. T. (1999). Ongoing crisis communication. Thousand Oaks, CA: SAGE Publications.

Coombs, W. T. (2007). Protecting organization reputations during a crisis: The development and application of situational crisis communication theory. Corporate Reputation Review, 10, 163-176. http://dx.doi.org/10.1057/palgrave.crr.1550049

Coombs, W. T., \& Holladay, S. J. (2002). Helping crisis managers protect reputational assets: Initial tests of the situational crisis communication theory. Management Communication Quarterly, 16(165), 165-186. http://dx.doi.org/10.1177/089331802237233

Cooper, A. H. (2002). Media framing and social movement mobilization: German peace protest against INF missiles, the Gulf War, and NATO peace enforcement in Bosnia. European Journal of Political Research, 41, 37-80. http://dx.doi.org/10.1111/1475-6765.00003

De Persgroep Advertising. (2013). Regionaal Verspreidingsgebied. Retrieved from http://www.persgroepadvertising.nl/regionaal

de Vreese, C. H. (2004). The effects of frames in political television news on issue interpretation and frame salience. Journalism E Mass Communication Quarterly, 81(1), 36-52. http://dx.doi.org/10.1177/107769900408100104 
Deephouse, D. L. (2000). Media reputation as a strategic resource: An integration of mass communication and resource-based theories. Journal of Management, 26(6), 1091-1112. http://dx.doi.org/10.1177/014920630002600602

Druckman, J. N. (2004). Political preference formation: Competition, deliberation, and the (ir)relevance of framing effects. American Political Science Review, 98(4), 671-686. http://dx.doi.org/10.1017/S0003055404041413

Edy, J. A., \& Meirick, P. C. (2007). Wanted, dead or alive: Media frames, frame adoption, and support for the war in Afghanistan. Journal of Communication, 57, 119-141. http://dx.doi.org/10.1111/j. 1460-2466.2006.00332.x

Entman, R. M. (1993). Framing: Toward clarification of a fractured paradigm. Journal of Communication, 43(4), 51-58. http://dx.doi.org/10.1111/j. 1460-2466.1993.tb01304.x

Gilpin, D. R. (2008). Narrating the organizational self: Reframing the role of the news release. Public Relations Review, 34(1), 9-18.

Gunther, A. C. (1998). The persuasive press inference: Effects of mass media on perceived public opinion. Communication Research, 25(5), 486-504. http://dx.doi.org/10.1177/009365098025005002

Hansen, K. (2007). The sophisticated public: The effect of competing frames on public opinion. Scandinavian Political Studies, 30(3), 377-396. http://dx.doi.org/10.1111/j. 1467-9477.2007.00185.x

HOI, Instituut voor Media Auditing. (2011). HOI Rapportage 2011. Retrieved from http://hoi-offline.staging.modernmedia.nl/798/Opvraagmodule.htm

Iyengar, S. (1987). Television news and citizens' explanations of national affairs. The American Political Science Review, 81(3), 815-832. Retrieved from http://www.jstor.org/stable/1962678

Kim, S.-H., Carvalho, J. P., \& Cooksey, C. E. (2007). Exploring the effects of negative publicity: News coverage and public perceptions of a university. Public Relations Review, 33, 233-235. http://dx.doi.org/10.1016/j.pubrev.2007.02.018

Kuttschreuter, M., Gutteling, J. M., \& de Hond, M. (2011). Framing and tone-of-voice of disaster media coverage: The aftermath of the Enschede fireworks disaster in the Netherlands. Health, Risk E' Society, 13(3), 201-220.

McCombs, M. (1977). Agenda setting function of mass media. Public Relations Review, 3(4), 89-95. http://dx.doi.org/10.1016/S0363-8111(77)80008-8

McCombs, M. (2004). Setting the agenda: The mass media and public opinion. Cambridge: Polity Press.

McCombs, M., \& Ghanem, S. I. (2001). The convergence of agenda setting and framing. In S. D. Reese, O. H. Gandy Jr., \& A. E. Grant (Eds.), Framing public life: Perspectives on media and our understanding of the social world (pp. 67-81). Mahwah, NJ: Lawrence Erlbaum Associates, Inc.

Meijer, M. M., \& Kleinnijenhuis, J. (2006). News and corporate reputation: Empirical findings from the Netherlands. Public Relations Review, 32(4), 341-348. http://dx.doi.org/10.1016/j.pubrev.2006.08.002

Miller, M. M., \& Riechert, B. P. (2000). Interest group strategies and journalistic norms: news media framing of environmental issues. In S. Allan, B. Adam, \& C. Carter (Eds.), Environmental risks and the media. London: Routledge.

Nelkin, D. (1988). Risk reporting and the management of industrial crises. Journal of Management Studies, 25(4), 341-351. http://dx.doi.org/10.5465/AMR.1998.192960

Neuman, W. R., Just, M. R., \& Crigler, A. N. (1992). Common knowledge: News and the construction of political meaning. Chicago: The University of Chicago Press.

Price, V., Tewksbury, D., \& Powers, E. (1997). Switching trains of thought: The impact of news frames on readers' cognitive responses. Communication Research, 24(5), 481-506. http://dx.doi.org/10.1177/009365097024005002

Ritchie, B. W., Dorell, H., Miller, D., \& Miller, G. A. (2004). Crisis communication and recovery for the tourism industry. Journal of Travel E' Tourism Marketing, 15(2-3), 199-216. http://dx.doi.org/10.1300/J073v15n02_11

Semetko, H. A., \& Valkenburg, P. M. (2000). Framing European politics: A content analysis of press and television news. Journal of Communication, 50(2), 93-109. http://dx.doi.org/10.1111/j.1460-2466.2000.tb02843.x

Stephens, K. K., \& Malone, P. C. (2009). If the organizations won't give us information. ..: The use of multiple new media for crisis technical translation and dialogue. Journal of Public Relations Research, 21(2), 229-239. http://dx.doi.org/10.1080/10627260802557605

Ulmer, R. R., Sellnow, T. L., \& Seeger, M. W. (2007). Effective crisis communication: Moving from crisis to opportunity. Thousand Oaks, CA: SAGE Publications.

Valentini, C., \& Romenti, S. (2011). The press and Alitalia's 2008 crisis: Issues, tones, and frames. Public Relations Review, 37(2011), 360-365. http://dx.doi.org/10.1016/j.pubrev.2011.07.002

Valkenburg, P. M., Semetko, H. A., \& de Vreese, C. H. (1999). The effects of news frames on readers' thoughts and recall. Communication Research, 26(5), 550-569. http://dx.doi.org/10.1177/009365099026005002

Veil, S. R., \& Ojeda, F. (2010). Establishing media partnerships in crisis response. Communication Studies, 61(4), 412-429. http://dx.doi.org/10.1080/10510974.2010.491336 